\title{
Emissions down the drain: Balancing life cycle energy and greenhouse gas savings with resource use for heat recovery from kitchen drains
}

Schestak, Isabel; Spriet, Jan; Styles, David; Williams, Prysor

\section{Journal of Environmental Management}

DOI:

10.1016/j.jenvman.2020.110988

Published: 01/10/2020

Peer reviewed version

Cyswllt i'r cyhoeddiad / Link to publication

Dyfyniad o'r fersiwn a gyhoeddwyd / Citation for published version (APA):

Schestak, I., Spriet, J., Styles, D., \& Williams, P. (2020). Emissions down the drain: Balancing life cycle energy and greenhouse gas savings with resource use for heat recovery from kitchen drains. Journal of Environmental Management, 271, [110988].

https://doi.org/10.1016/j.jenvman.2020.110988

\footnotetext{
Hawliau Cyffredinol / General rights

Copyright and moral rights for the publications made accessible in the public portal are retained by the authors and/or other copyright owners and it is a condition of accessing publications that users recognise and abide by the legal requirements associated with these rights.

- Users may download and print one copy of any publication from the public portal for the purpose of private study or research.

- You may not further distribute the material or use it for any profit-making activity or commercial gain

- You may freely distribute the URL identifying the publication in the public portal ?
}

Take down policy

If you believe that this document breaches copyright please contact us providing details, and we will remove access to the work immediately and investigate your claim. 
1 Emissions down the drain: Balancing life cycle energy and 2 greenhouse gas savings with resource use for heat recovery from 3 kitchen drains

Isabel Schestak ${ }^{a,}$, Jan Spriet ${ }^{\mathrm{b}}$, David Styles $^{\mathrm{a}, \mathrm{c}}$, A Prysor Williams $^{\mathrm{a}}$

a School of Natural Sciences, Bangor University, Deiniol Road, LL57 2UW, Bangor, Gwynedd, United

6 Kingdom

${ }^{b}$ Department of Civil, Structural and Environmental Engineering, Trinity College, The University of

8 Dublin, College Green, Dublin 2, Ireland

9 c School of Engineering, University of Limerick, Limerick, V94 T9PX, Ireland.

•Corresponding author. E-mail address: isabel.schestak@bangor.ac.uk Tel.: +44-1248-383219

\section{Abstract}

Although the food service sector is a major user of water, the potential for heat recovery from commercial kitchens' drain water remains largely unexplored. For the first time, we compare the life cycle environmental burdens of producing and installing a heat recovery system with the environmental credits arising from energy savings for a restaurant case study, and for the entire UK food service sector. Life Cycle Assessment was applied to determine the impacts of heat recovery systems made from different materials and comprising a heat exchanger in the shape of a concentric double-walled pipe, pipework and fittings. The design option with the smallest environmental footprint combined a heat exchanger made out of polypropylenegraphite (PP-GR) with polyethylene pipework, exhibiting 80-99\% less environmental impact compared with components made out of (35\% recycled) copper. Contrasting the environmental impacts of two heat recovery set-ups with energy savings shows that a PP-GR based system pays back all seven assessed environmental impacts within two years, while payback times for the copper-based system vary depending on the replaced energy source, and can exceed the 10 year operational lifetime of the system. When looking at typical flowrates in UK food outlets, net environmental savings can be realised across all analysed impact categories above a threshold water consumption of 555 L/day, using current technology. Extrapolation to the UK food service sector indicates annual greenhouse gas emission mitigation potential of about $500 \mathrm{Gg} \mathrm{CO}_{2}$ equivalent.

\section{Keywords}

Environmental impact assessment, wastewater heat recovery, energy savings, eco-design, climate change mitigation, recycling

\section{Introduction}

In the UK, nearly half of the water consumption of the wider food and drink sector occurs in the hospitality and food service sub-sector, with an estimated 143 million $\mathrm{m}^{3}$ water used in 2010 for the preparation of meals in commercial and similarly used kitchens (Bromley- 
recovery potential for the UK food service sector of $1.4 \mathrm{TWh} / y e a r$, and a financially viable potential of 1.24 TWh/year. The recovered heat is available for direct reuse for pre-heating the cold water supply and can hence directly contribute to the decarbonisation of hot water use. Heating water accounts for a considerable amount of energy consumption across industrial and non-industrial sectors. It is estimated that up to about $90 \%$ of the energy requirements and related greenhouse gas (GHG) emissions from the domestic water cycle in industrialised countries derive from heating water (Arpke and Hutzler, 2008; DEFRA, 2008; Fagan et al., 2010; Gerbens-Leenes, 2016; Nair et al., 2014; Siddiqi and Fletcher, 2015). Sanders and Webber (2012) looked into the energy consumption for water use of all sectors in the US, and found that heating for hot water and steam generation dominated water-related energy consumption not only in the residential, but also the commercial and industrial sector. Altogether, $47 \%$ of the US primary energy consumption in 2010 was due to water and steam applications (Sanders and Webber, 2012).

While heat recovery from wastewater has been intensively studied and applied in the residential sector, this is not the case for the food service sector, although the same appliances can be used. The necessary equipment for heat recovery from drain water on a small-scale includes market-ready low-tech options such as in-line, pipe shaped heat exchangers (Ip et al., 2018; McNabola and Shields, 2013; Schuitema et al., 2005; van der Hoek, 2011). They have been predominantly studied and installed for use in households or similar domestic settings for shower or mixed drain water (Ip et al., 2018; McNabola and Shields, 2013; Schuitema et al., 2005; Słyś and Kordana, 2014; Wong et al., 2010). However, they could also be potentially used with other wastewater types.

A bonus of heat recovery from commercial kitchens' drain water is a higher daily water use compared to an average household, which for the UK lies in the range of 360 to 12,500 L/day (Spriet and McNabola, 2019a), versus to 349 L/day in homes (EST, 2013). The heat recovery figures by Spriet and McNabola (2019a) equate to an average yearly saving of about $5400 \mathrm{kWh}$ per food outlet. Installation of comparable heat recovery systems with showers have been reported to save 127-1880 kWh/year per six showers in a sports facility (Ip et al., 2018), and 130-508 kWh/year per one shower in a residential building (Wong et al., 2010). The amount of heat energy recovered during the lifetime of the heat recovery system plays an important role not only for financial payback, but also environmental payback for the installation.

As with all manufactured products, heat recovery devices carry environmental burdens through their manufacture, installation works, operation and disposal. Significant burdens from manufacture are especially associated with metals such as copper, which is frequently used for plumbing equipment and a preferred material for heat exchangers because of excellent heat conducting properties. It is known that production of copper components generates larger environmental burdens compared to steel (Prek, 2004) or plastic (Asadi et al., 2016; Franklin Associates, 2011), with regard to GHG emissions (Franklin Associates, 2011), human health and eutrophication impacts (Asadi et al., 2016). Hence, to justify the application of heat recovery devices on resource efficiency and wider environmental grounds, the impacts generated during their life cycle have to be considered. However, there is a lack of studies evaluating in-line heat recovery devices for small-scale applications, and providing the complete picture of environmental impacts through full Life Cycle Assessment (LCA). The most comprehensive related study was published by Ip et al. (2018), who conducted an environmental and economic assessment of an in-line heat exchanger from copper recovering heat from shower drains in a university sports facility. Whilst their LCA study comprised all steps, from cradle to grave (manufacture, use and end-of-life) of the heat exchanger, it only considered the Global Warming Potential (GWP) burden; i.e. GHG emissions. Other impact 
categories such as resource depletion with material component manufacture were not included. The study also did not consider the need for additional pipework or fittings that can be necessary to connect the heat recovery device to a boiler, especially when retrofitting an existing plumbing system.

Here, we apply LCA methodology to determine for the first time the environmental burdens across seven impact categories arising from the manufacture and retrofit installation of a full drain water heat recovery system suitable for use with kitchen drain water. Besides the essential heat exchanger, the system consists of the pipework required for connecting the heat exchanger to a boiler and cold water supply, of insulation and fittings. Due to important potential environmental trade-offs associated with copper highlighted in aforementioned studies, we explore the use of recycled copper and of a polymer based material as alternative, namely polypropylene-graphite (PP-GR). For pipework, different materials (copper, steel, polyethylene) and different lengths are considered, in order to represent different sitedependent conditions.

As the amount of recoverable heat and the benefits derived from avoided water heating significantly influence the environmental sustainability of heat recovery systems, LCA results are compared to energy savings from different sizes of kitchens used for different purposes: the comparison includes savings from a case study restaurant and from commercial kitchens across the UK food service sector. Eventually, extrapolation of the findings to the UK food service sector determines the potential savings on a national level.

\section{Materials and methods}

\subsection{Goal and Scope}

The objective of this study is to provide a comprehensive picture of the environmental burdens of a heat recovery system retrofitted to a commercial kitchen, to identify the steps in the life cycle contributing most to these environmental burdens and to explore the role for alternative materials to mitigate "hotspots" of environmental impacts, and inform eco-design. The LCA approach has been chosen for this purpose, following the guidelines of ISO 14040 (ISO, 2006). An LCA accounts for resource use and emissions arising during the life of a product or service, starting with resource extraction and mining, and ending with its disposal or alternative end-of-life (EoL) management. In the case of the copper pipe, it includes for instance the mining of the copper ore, through processing of the copper such as melting and extrusion, to recycling into new copper products.

Environmental impacts are classified into different impact categories, with Global Warming Potential (GWP) caused by GHG emissions being the most prominent one. We furthermore chose the following environmental impact categories from the set of categories and characterisation methods recommended at midpoint level by the International Reference Life Cycle Data System (ILCD) (EC JRC 2011): Human Toxicity Potential (HTP) and Freshwater Ecotoxicity Potential (FEToxP), as these impacts are associated to mining activities such as copper mining; Mineral, fossil \& renewable Resource Depletion Potential (RDP), as nearly all parts of the heat recovery systems assessed are made from finite materials and changes are expected with different recycled material input rates; Freshwater Eutrophication Potential (FEP), Acidification Potential (AP), and Photochemical Ozone Formation Potential (POFP), as they are connected to a variety of industrial processes such as mining, fossil fuel combustion in heat and electricity generation as well as transport. Eutrophication is furthermore associated with energy generation from biomass. HTP is presented as sum of both the cancer and non- 
cancer toxicity potential. Normalised scores have been obtained in SimaPro, with normalisation factors based on Benini et al. (2014).

137 The life cycles of the heat recovery systems are modelled with the software SimaPro (release 9.0) (PRé Sustainability, 2018) and using the Ecoinvent (2018) version 3.5 database for the life cycle inventory for the majority of processes (see Supplementary Material S1 for additional databases used).

\subsection{System boundaries}

The LCAs include all stages from cradle-to-grave, i.e. from the extraction of the raw materials incorporated in the processes chosen from the database until the end of life of the products (Figure 1). No environmental burdens are considered to arise during the use phase, as the device itself is passive and not expected to create any emissions. Maintenance (i.e. cleaning) intervals are unknown, and cleaning burdens are estimated to be minor compared to overall lifecycle burdens. Packaging and transport are included. Transport is part of both the foreground system and the background system through choice of appropriate processes from the databases (Supplementary Material S1).

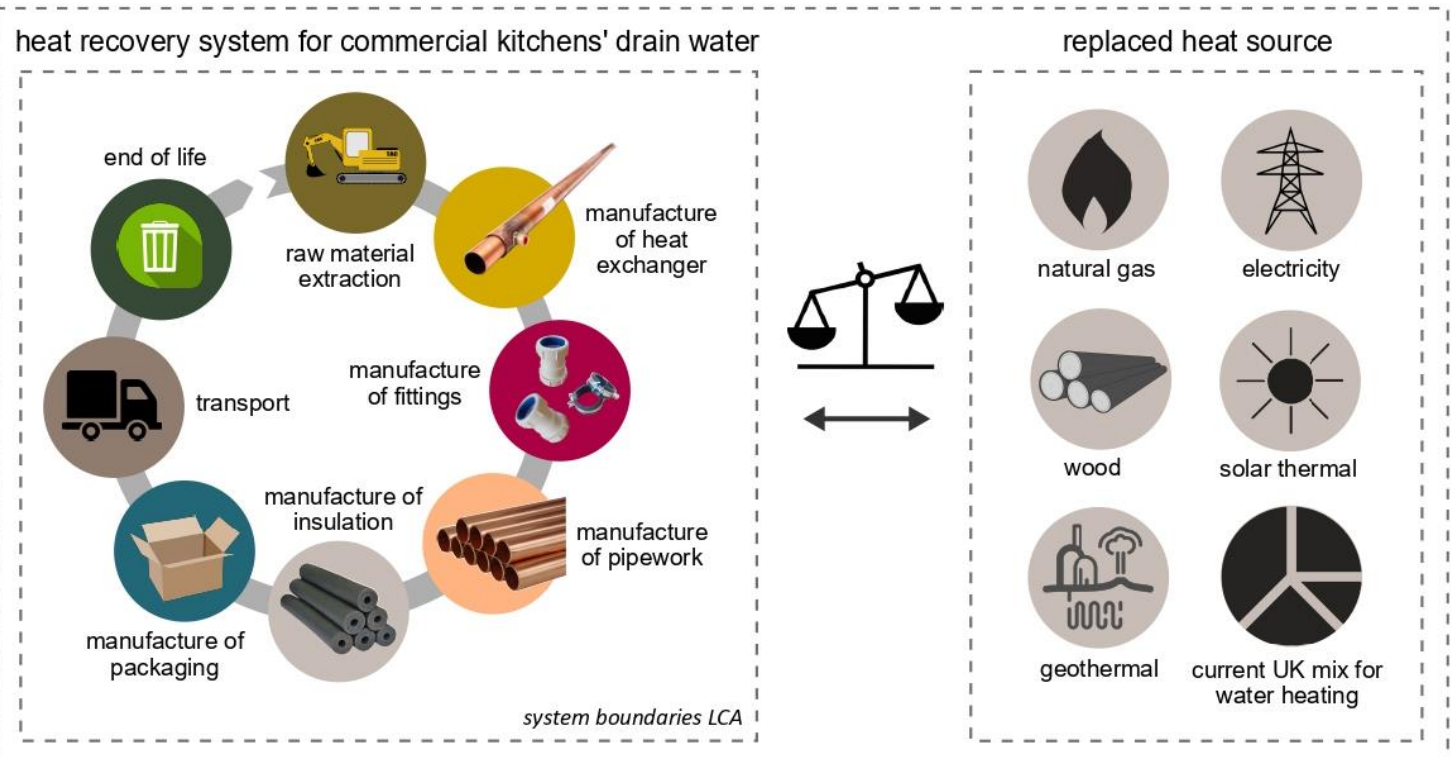

Figure 1: System boundaries of the LCAs on the heat recovery system (left, shown for the copper system) and extended boundaries for evaluating the savings potential through the replacement of heat energy sources.

\subsection{Description of the system and inventory}

\subsubsection{Overview}

The core part of the heat recovery system is the heat exchanger designed as a concentric double-walled pipe which replaces a part of the wastewater pipe. The warm wastewater flows through the inner pipe, while the cold incoming water flows in the opposite direction through the outer pipe (counter flow principle, Supplementary Material S2). For a fully functional heat exchanger and maximum heat recovery, the warm drain water has to form a falling film along the wall of the inner pipe (Manouchehri et al., 2015). This is enabled through a vertical installation (Manouchehri et al., 2015). The heat exchanger is connected to the existing pipework via plastic fittings (bottom and top connectors) with joint rings, one fitting each end 

exchanger at the wall (BPD Itd., 2019a).

The pre-heated incoming water is led from the heat exchanger to the conventional heating system, usually a boiler, for further heating. Depending on the layout of the existing plumbing in a building, the heat exchanger cannot be placed in close vicinity to the boiler or the incoming cold water pipe and additional pipework can be required to cross the distance. To minimise heat loss, the pipework is considered to be insulated with a layer of synthetic rubber.

An overview of the inventory is provided in the Supplementary Material S1.

\subsubsection{Manufacture of the copper heat exchanger}

Description: The heat exchanger considered refers to a model which is $1.68 \mathrm{~m}$ long, has an inner diameter of $48 \mathrm{~mm}$ and weighs $6.1 \mathrm{~kg}$ (Q-Blue b.v., 2018). The capacity for the drain water flow is $50 \mathrm{~L} / \mathrm{min}$, and the maximum clean water flow is $12 \mathrm{~L} / \mathrm{min}$. The clean water void between the inner and outer cylinder has a volume of $0.39 \mathrm{~L}$.

Modelling: Starting with primary or recycled copper, the production of a semi-finished copper tube continues with the following steps: melting, casting, extrusion, drawing and finishing steps from the raw pipe to the final heat exchanger (Tikana et al., 2005). As the processes of melting and casting are already included in an Ecoinvent database process for primary copper production, they are only modelled separately for the recycled copper. For melting the secondary copper, we assume the electricity input for an induction furnace, which is the type of furnace predominantly used in the copper industry (CDA Inc., 2019). The energy requirement for melting of copper in an induction furnace is calculated according to basic physical principles and a plant efficiency of 70\% (Dötsch, 2017) (Supplementary Material S3).

As primary copper production is a resource- and energy-intensive process, responsible for considerable emissions during mining, ore refining and further processing (Althaus and Classen, 2005; Castro Molinare, 2014), adequate assumptions for the share of recycled copper in the heat exchanger are necessary for a realistic picture of its environmental impacts. Two types of recycled or secondary copper can be distinguished: recycled scrap, which originates from low grade copper scrap and which has to be refined electrolytically before reuse; and clean scrap, which can be directly re-melted.

192 Studies from Ciacci et al (2017) and Glöser et al (2013) estimated an average 35\% recycling input rate for all types of copper products in Europe and globally, of which $63 \%$ is clean scrap. Another study, commissioned by the copper industry and claiming to rely on primary industry data, assumes a share of around $70 \%$ of recycled copper as input for the production of European copper pipes, of which about $90 \%$ comes from clean scrap (Tikana et al., 2005).

\section{7}

\subsubsection{Manufacture of the PP-GR heat exchanger}

PP-GR has been chosen in this study as a potential substitute for copper in a wastewater heat exchanger for several reasons. It exhibits a greater fouling and corrosion resistance compared to metals, which is important when conveying media heavily loaded with organic material, such as kitchen wastewater (Chen et al., 2016; Hussain et al., 2017, Glade et al., 2018). As PP-GR has been tested and designed for use in highly corrosive environments such as desalination plants and with higher temperatures than those of kitchen wastewater, we expect the material to be appropriate to handle wastewater (Glade et al., 2018; Technoform, 2014). From an environmental perspective, a great advantage is the smaller amount of energy required for forming polymers, compared with metals. 
Description: There is no commercially available heat exchanger made from PP-GR to date that is equivalent to the copper model evaluated here. Material requirements are therefore calculated for a hypothetical heat exchanger with the same length and volume for the water leading parts in order to compare the amount of recovered heat. As PP-GR has a considerably lower density than copper, at $1.56 \mathrm{~g} / \mathrm{cm}^{3}$, only $1.02 \mathrm{~kg}$ material is required. The PP-GR composite is made of polypropylene as a matrix with graphite as filler, imparting a thermal conductivity comparable to that of stainless steel (Glade et al., 2018). PP-GR contains 72 wt\% graphite, equalling 50 vol\% (Glade et al., 2018).

Modelling: Information on the material composition and properties were attained from a manufacturer (Technoform, 2014) as well as from a study on its mechanical, chemical and thermal properties (Glade et al., 2018). Virgin polypropylene and battery grade graphite are considered as the inputs for the PP-GR pipe. Battery grade graphite production requires energy intensive steps, comes with a higher environmental burden than that for graphical paper and is therefore selected as a conservative proxy, so as not to underestimate environmental burden (Olson et al., 2016). The tube is produced through an extrusion process.

In contrast to the copper device, no field data are available for the heat recovery potential of the PP-GR heat exchanger in the discussed application. But given a heat transfer coefficient of the PP-GR tube of $2523 \mathrm{~W} /\left(\mathrm{m}^{2 *} \mathrm{~K}\right)$ (Technoform, 2014), we can determine an effectiveness of $60.5 \%$, close to that of the copper heat exchanger of $58 \%$ on average, according to the manufacturer (Q-Blue b.v. 2018, Spriet and McNabola, 2019a) (Supplementary Material S4). Heat recovery potential by the PP-GR device is therefore conservatively assumed to be equal to that for copper.

\subsubsection{Pipework, insulation, fittings and packaging}

230

Pipework required to retrofit the heat exchanger within the existing plumbing network is also accounted for. The outer diameter of this pipework is $28 \mathrm{~mm}$ (DN25), and we consider three lengths to represent different retrofit situations: $1 \mathrm{~m}, 10 \mathrm{~m}$ (the length required in the case study), and $30 \mathrm{~m}$. Copper, steel and polyethylene are compared as pipe materials. Information to model the pipework was retrieved from pipe manufacturers for copper (German Pipe, 2019), polyethylene (Pipelife UK, 2019) and stainless steel (Geberit Sales Ltd, 2019). The insulation is modelled using a pipe insulation module from Ecoinvent, which refers to insulation made from the synthetic rubber ethylene propylene diene methylene (EPDM). Information on the quantities and types of material of the fittings were derived from a manufacturer and a supplier (BPD Itd., 2019b; Q-Blue b.v., 2018). The weights of the parts and packaging were determined directly by the authors.

\section{$241 \quad 2.3 .5 \quad$ Transport}

The city of Birmingham has been chosen as a representative, central location within the UK for installation of the heat recovery system. The copper heat exchanger and the fittings are considered to be shipped from the Netherlands to the UK by lorry, unless more specific information has been provided by a supplier for particular fittings (Livingston, 2018). Two parts of the top connector are produced in Poland, and the third part is made in the UK along with the entire bottom connector. The PP-GR heat exchanger in contrast is shipped from the production site in Kassel, Germany. The pipework and insulation is assumed to originate from Germany. The transport from the site of use to a recycling facility or landfill site is considered using a generic distance of $100 \mathrm{~km}$. 


\subsubsection{End-of-Life}

252 The LCAs regard recycling for parts where a recycling infrastructure exists in the UK, and 253 landfill where recycling is unlikely. Different methodologies exist to allocate burdens for 254 recyclable materials in LCA (Ekvall and Tillman, 1997; Johnson et al., 2013). Here, we opt for the cut-off or recycled content approach (Johnson et al., 2013) and hence do not account for emissions and benefits from recycling in the EoL stage, as the recycling benefits and burdens in the manufacturing stage are already taken into account, where applicable. For copper, we assume recycling of $80 \%$, which is the EoL processing rate for European plumbing equipment as determined by Ruhrberg et al. (2006). The remaining copper is considered to go to landfill. Bottom and top connectors are recycled completely, as their size allows for municipal waste management for hard plastics. Brackets and screws are assumed to go to landfill, as it is unlikely that the user will deconstruct and separate these small components to allow for recycling. For insulation, material is considered to be sent to a landfill for disposal (BIF REP, 2013). Pipework: Copper pipework follows the same EoL route as the heat exchanger from copper. Steel is recycled at a rate of 70\% (Davis et al., 2006) and polyethylene EoL is split into recycling (16\%), incineration (35\%) and landfill (49\%) (Mudgal et al., 2011) (see Supplementary Material S1 for details).

As the PP-GR composite is a relatively new material on the market, we conservatively assume landfill as the most likely fate, accounting for both polypropylene and the inert graphite.

\subsection{Scenarios and functional unit}

A range of scenarios has been adopted for the setup of the heat recovery system in order to represent various installation settings and compare different design options. The five scenarios are listed in Table 1. They all include the functional unit of a heat recovery system with one in-line heat exchanger, pipework of $10 \mathrm{~m}$ length and fittings. Separate from these scenarios, we assess the design options for the pipework, comparing copper, steel and polyethylene pipework and lengths of 1,10 and $30 \mathrm{~m}$.

Table 1: Overview of assumptions for scenarios of the LCAs.

\begin{tabular}{|c|c|c|c|c|c|}
\hline Scenario & Name & $\begin{array}{c}\text { Number of heat } \\
\text { exchangers }\end{array}$ & Material heat exchanger & Material pipework & Length pipework \\
\hline 1 & Copper $(0 \%)$ & ( & $\begin{array}{c}\text { Copper }(0 \% \text { recycled } \\
\text { content) }\end{array}$ & $\begin{array}{c}\text { Copper ( } 0 \% \text { recycled } \\
\text { content) }\end{array}$ & $10 \mathrm{~m}$ \\
\hline 2 & Copper (35\%) & 1 & $\begin{array}{c}\text { Copper (35\% recycled } \\
\text { content) }\end{array}$ & $\begin{array}{c}\text { Copper (35\% recycled } \\
\text { content) }\end{array}$ & $10 \mathrm{~m}$ \\
\hline 3 & Copper $(70 \%)$ & 1 & $\begin{array}{c}\text { Copper (70\% recycled } \\
\text { content) }\end{array}$ & $\begin{array}{c}\text { Copper }(70 \% \text { recycled } \\
\text { content) }\end{array}$ & $10 \mathrm{~m}$ \\
\hline 4 & Copper $(35 \%)+\mathrm{PE}$ & 1 & $\begin{array}{c}\text { Copper (35\% recycled } \\
\text { content) }\end{array}$ & Polyethylene & $10 \mathrm{~m}$ \\
\hline 5 & $P P-G R+P E$ & 1 & $\begin{array}{c}\text { Polypropylene-graphite (PP- } \\
\text { GR) }\end{array}$ & Polyethylene & $10 \mathrm{~m}$ \\
\hline
\end{tabular}

For the operational lifetime, we assume a conservative duration of 10 years. Other studies considered a 50-year lifetime for a copper heat exchanger or copper pipework (Asadi et al., 2016; Ip et al., 2018), but damage through corrosion is likely to occur earlier with kitchen wastewater as it carries a greater load of organic pollutants than shower drain or clean water. The functional unit for the case of an average UK kitchen is $1 \mathrm{kWh}$ of water heating delivered through heat recovery.

\subsection{Savings potential}

In order to determine the potential environmental savings associated with use of the heat recovery system, data on recovered heat are required. We look at two different cases: 
Case study: Firstly, LCA results are set into context with data on heat recovery from a case study on the restaurant kitchen of Penrhyn Castle in Bangor, North Wales, UK, which is open to visitors as a tourist attraction. Spriet and McNabola (2019b) predicted the amount of recovered heat during an 8-month monitoring study to be $8.45 \mathrm{kWh}$ per day, taking into account the following: a copper heat exchanger as described above, a measured average daily water consumption of $652.5 \mathrm{~L}$, a $90 \%$ return rate of the consumed water into the drain, a retention time of water through kitchen appliances of no longer than 1 hour and measured average drain water temperatures of 25 to $35^{\circ} \mathrm{C}$ (Supplementary Material S4). As the pipework is insulated and as time between heat recovery and consumption of the pre-heated water is very short, heat losses in the pipe are considered negligible. We consider the restaurant to be open 310 days a year. The environmental impacts realised through heat recovery are compared to the avoided impacts when replacing different conventional and renewable energy sources for water heating: natural gas, UK grid electricity, woodchips, geo and solar thermal energy, and the energy mix for water heating in the UK service sector (BEIS, 2018) (Table 2; Supplementary Material S5 for environmental burdens from the energy mix). Results are presented as payback times for heat recovery when it replaces the mentioned energy sources.

Life cycle burdens of the heat recovery systems as in scenario 2 and 5 are considered. Scenario 2 represents the actual installations carried out at the case study site where only copper equipment was used. Scenario 5 has been selected to show potential savings with polymer-based materials.

Table 2: Types of energy and respective database modules used for determination of environmental savings through heat recovery

\begin{tabular}{|c|c|c|c|}
\hline Energy type & Database module & Database & $\begin{array}{l}\text { Share in UK } \\
\text { water } \\
\text { heating mix } \\
{[\%]^{*}}\end{array}$ \\
\hline Natural gas & Heat, central or small-scale, natural gas $\{$ Europe without Switzerland\}| market for & Ecoinvent & 66 \\
\hline Grid electricity & Electricity, low voltage $\{G B\} \mid$ market for & Ecoinvent & 14 \\
\hline Oil & $\begin{array}{l}\text { Heat, central or small-scale, other than natural gas }\{\text { Europe without Switzerland\}| heat } \\
\text { production, light fuel oil, at boiler } 10 \mathrm{~kW} \text { condensing, non-modulating }\end{array}$ & Ecoinvent & 12 \\
\hline $\begin{array}{l}\text { Softwood } \\
\text { chips }\end{array}$ & $\begin{array}{l}\text { Heat, central or small-scale, other than natural gas }\{\mathrm{CH}\} \mid \text { heat production, softwood chips } \\
\text { from forest, at furnace } 50 \mathrm{~kW} \text {, state-of-the-art } 2014\end{array}$ & Ecoinvent & 4 \\
\hline $\begin{array}{l}\text { Hardwood } \\
\text { chips }\end{array}$ & $\begin{array}{l}\text { Heat, central or small-scale, other than natural gas }\{\mathrm{CH}\} \mid \text { heat production, hardwood chips } \\
\text { from forest, at furnace } 50 \mathrm{~kW} \text {, state-of-the-art } 2014\end{array}$ & Ecoinvent & 1 \\
\hline Straw & $\begin{array}{l}\text { Heat, district or industrial, other than natural gas }\{G L O\} \mid \text { heat production, straw, at furnace } \\
300 \mathrm{~kW}\end{array}$ & Ecoinvent & 3 \\
\hline Geothermal & $\begin{array}{l}\text { Heat, borehole heat pump \{Europe without Switzerland\}| heat production, borehole heat } \\
\text { exchanger, brine-water heat pump } 10 \mathrm{~kW}\end{array}$ & Ecoinvent & n.a. \\
\hline Solar thermal & $\begin{array}{l}\text { Heat, central or small-scale, other than natural gas }\{\mathrm{CH}\} \mid \text { operation, solar collector system, } \\
\text { evacuated tube collector, one-family house }\end{array}$ & Ecoinvent & n.a. \\
\hline
\end{tabular}

*current UK energy mix for heating water in the service sector (BEIS, 2018). The category "biomass" was split into softwood chips, hardwood chips and straw in order to best reflect the current use of biomass heat sources (BEIS 2018b, Forest Research 2018, DEFRA 2017).

Neglected: bioenergy from (unless included in grid electricity): landfill gas, sewage gas, waste wood, animal biomass, anaerobic digestion and biodegradable energy from waste.

312 UK commercial food outlets: Secondly, we determine the environmental sustainability of a 313 heat recovery system when used with typical water consumption rates prevalent in UK commercial food outlets. The water consumption rates refer to the average rates of different food outlet categories (Spriet and McNabola, 2019a), ranging from 360 to 12,500 L/day. Heat recovery data were determined as in Spriet and McNabola (2019a), (Supplementary Material S4), taking into account the number of heat exchangers optimised for maximum financial payback with 310 open days a year over a 10 year lifetime i.e. for greater flow-rates, the 
installation of several heat exchangers in parallel is considered (Supplementary Material S6). 320 The life cycle burdens taken into account for the heat recovery system refer to scenario 4 .

321

322

323

Finally, data on the number of served meals, water consumption and the number of outlets in the hospitality and food service sector serve to extrapolate the environmental savings to a UK level (Backman, 2018; Bromley-Challenor et al., 2013; Spriet and McNabola, 2019a).

\section{Results and Discussion}

\subsection{Life Cycle Assessment results}

326

327

328

329

330

331

332

333

334

335

336

337

338

339

340

341

Figure 2 shows the characterised LCA results of all scenarios for the drain water heat recovery system. The different materials used for the scenarios lead to large differences between their footprints. There are clear benefits from increasing the share of recycled copper or fully replacing copper with polymer materials. Production, use and end-of-life of the copper systems emit 87,81 and $71 \mathrm{~kg}$ of $\mathrm{CO}_{2}$ equivalent, respectively, depending on the recycled material input. These numbers coincide with the findings of Giurco and Petrie (2007) who found an increase in recycling rates besides demand reduction the only strategy to meet GHG reduction targets for copper production as ever lower ore grades constrain the potential to decarbonise copper ore processing.

A combination of a copper heat exchanger with polyethylene pipework has a GWP of $39 \mathrm{~kg}$ $\mathrm{CO}_{2}$ equivalent. Reductions in burdens of around $45-50 \%$ can be achieved for HTP, FEP, FEtoxP and RDP, when switching from a heat exchanger and pipework of zero percent recycled copper to one of $70 \%$ recycled copper. Replacement of the $35 \%$-copper pipework through PE can lower the impacts of the whole system by $50-60 \%$ considering the heat exchanger is still made from 35\%-copper. Scenario 4 therefore represents the most environmentally friendly material combination currently available on the market for this set-up.

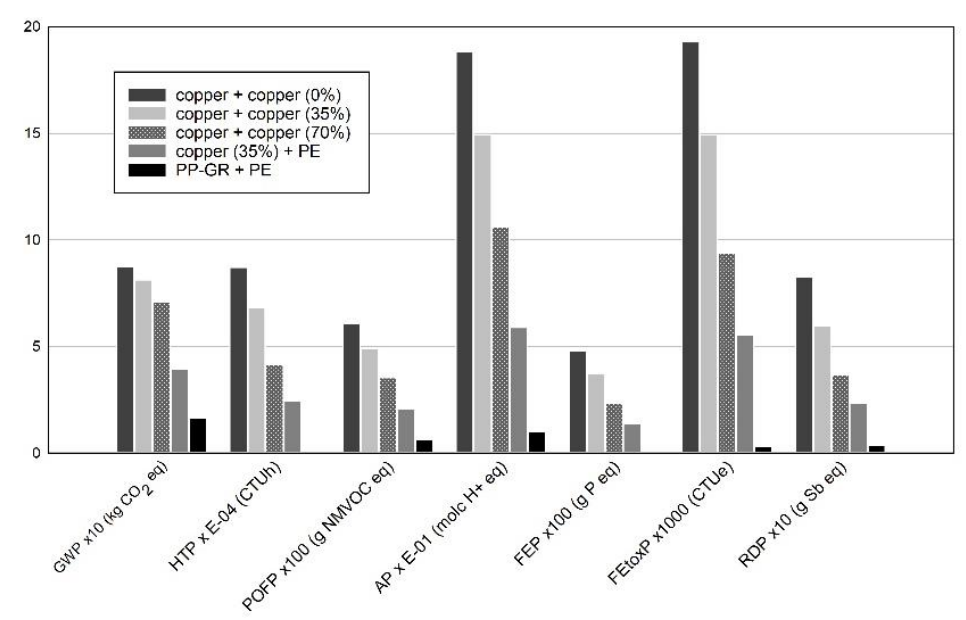

Figure 2: Environmental burdens arising from the life cycle of drain water heat recovery systems consisting of inline heat exchanger, $10 \mathrm{~m}$ pipework, fittings and insulations. Percentage in brackets stands for the share of recycled copper. PE: polyethylene, PP-GR: Polypropylene-Graphite. GWP: Global Warming Potential; HTP: Human Toxicity Potential; POFP: Photochemical Ozone Formation Potential; AP: Acidification Potential; FEP: Freshwater Eutrophication Potential; FEToxP: Freshwater Ecotoxicity Potential; RDP: Mineral, fossil \& renewable Resource Depletion Potential. All scenarios as described in Table 1.

348 Still though, a purely polymer based system with PP-GR performs considerably better with a impacts of the 35\%-copper scenario. Supplementary Material S7 shows the scenarios in a 
relative comparison to each other. The normalised results allow for inter-category comparison and show that the most relevant contributions are those to HTP and FEToxP for both systems 353 (Supplementary Material S8).

354 Ip et al. (2018) determined a GWP of $56 \mathrm{~kg} \mathrm{CO}_{2}$ equivalent for their copper heat exchanger, which would compare to 26,29 or $32 \mathrm{~kg} \mathrm{CO}_{2}$ equivalent for the life cycle of our copper heat exchanger alone with 70,35 or $0 \%$ recycled content, respectively (excluding pipework). Their study does not state the recycled copper input, making direct comparison difficult. Even so, one reason for the different results is certainly the different material requirement for the heat exchanger, with about $25 \mathrm{~kg}$ copper in Ip's study and about $6 \mathrm{~kg}$ in this study.

Figure 3 shows the relative contribution of the life cycle stages to the environmental burdens of heat recovery systems under scenario 2 and 5 . The majority of burdens of the copper system across all categories originate from manufacture of copper parts (heat exchanger and pipework), ranging from $87 \%$ of GWP burdens to $99 \%$ of HTP, FEP and FEtoxP burdens. This underlines the pollution associated with the extraction and manufacture of copper products discussed earlier in the introduction (Althaus and Classen, 2005; Castro Molinare, 2014). Indeed, the main burdens from the manufacture of heat exchanger and pipes derive from the generation of primary copper (Ecoinvent, 2018): HTP causing emissions arise mainly during the treatment of sulfidic tailings from primary copper production and comprise groundwater polluting zinc and arsenic (HTP non-cancer), and chromium VI (HTP cancer), amongst others. Similarly, FEToxP is mainly caused by zinc and copper emissions from tailing treatment and FEP predominantly through phosphate released into groundwater during the same process (Ecoinvent, 2018). The main substances responsible for POFP are nitrogen oxides emitted into the air during blasting, which also releases sulphur dioxide, the major cause for AP. Resource depletion is caused especially by use of the sulfidic copper ore and molybdenum during primary copper generation. Other resources contribute less than $1 \%$ to the RDP, hence RDP is almost exclusively due to the consumption of abiotic materials. Only for GWP, the finishing process of the heat exchanger and pipes has a greater influence than primary copper production driven by heat and electricity consumption. The impact from the pipework is greater than that from the heat exchanger, which is due to greater material use for the $10 \mathrm{~m}$ pipework (11 kg vs. 6 kg copper).

In the PP-GR system, the manufacture of the heat exchanger and pipework plays a comparatively smaller role. Apart from transport, all components make significant contributions to the lower overall impacts, depending on the category. Manufacture of the insulation from EPDM rubber accounts for $14-90 \%$ of burdens, with the greatest contribution going to RDP. The main resource depleted is indium during the operation of the zinc mine, zinc being an ingredient for the production of EPDM (Ecoinvent, 2018). EoL stage is mainly responsible for impacts in FEToxP (64\%), HTP (29\%) and GWP (16\%). FEToxP causing emissions in the EoL stage are arising from incineration and landfilling of the pipe material PE, both processes releasing vanadium into groundwater (Ecoinvent, 2018). The contribution of the predominantly cardboard packaging ranges from $4 \%$ (RDP) to $22 \%$ (FEP) across categories. 


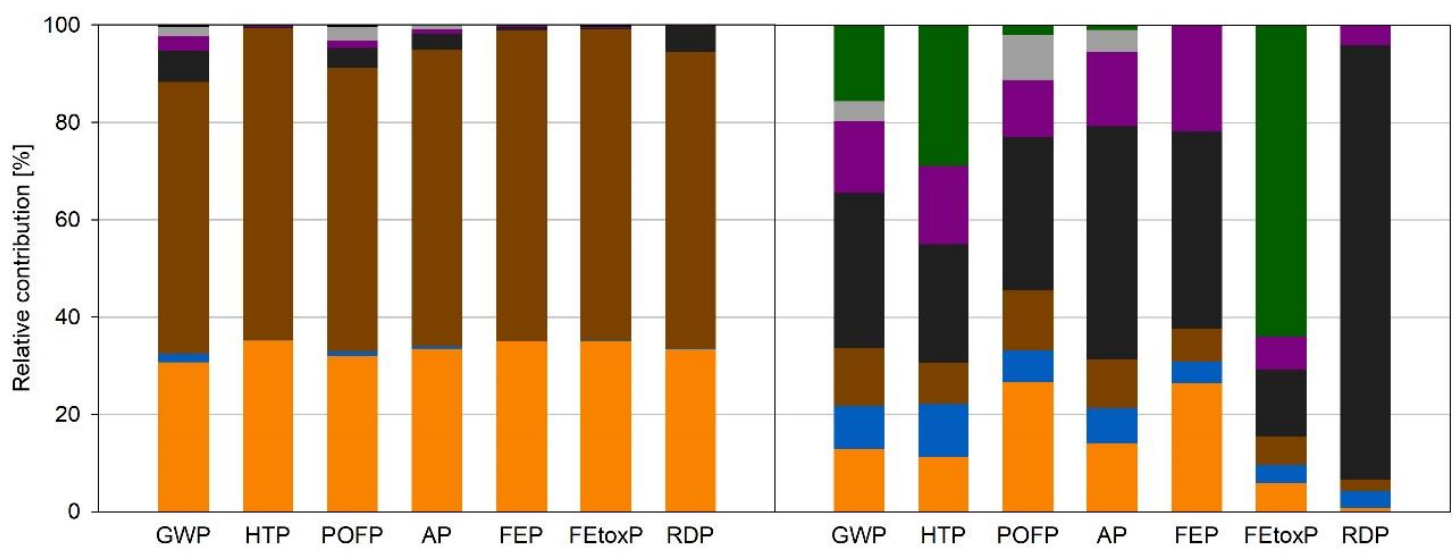

copper $(35 \%)$

PP-GR + PE

Figure 3: LCA of heat recovery systems (scenarios 2 and 5): Relative contribution of the life cycle stages to the environmental impacts of the two heat recovery systems including $10 \mathrm{~m}$ pipework. Left: scenario 2: copper system with 35\% recycled copper input. Right: scenario 5: PP-GR composite system with PP-GR heat exchanger and pipework from PE. GWP: Global Warming Potential; HTP: Human Toxicity Potential; POFP: Photochemical Ozone Formation Potential; AP: Acidification Potential; FEP: Freshwater Eutrophication Potential; FEToxP: Freshwater Ecotoxicity Potential; RDP: Mineral, fossil \& renewable Resource Depletion Potential; Hex: Heat exchanger; EoL: End of Life.

400 The length of the pipework greatly influences the overall LCA results. Figure 4 shows the 401 burdens from heat exchanger and pipework separately. Burdens for long and metal based 402 (steel or copper) pipework can be greater than those from the heat exchanger. Steel pipe 403 burdens are considerably lower than copper pipe burdens, ranging from 89\% (FEtoxP) to 15\% 404 (GWP) of those from copper (see Supplementary Material S9 for more impact categories). 405 These results underline the importance of considering the full equipment necessary for retrofit, and also how on-site conditions influence the environmental sustainability of a retrofit measure. As far as we are aware, this is the first LCA study of a heat recovery system to consider all associated retrofit pipework. 

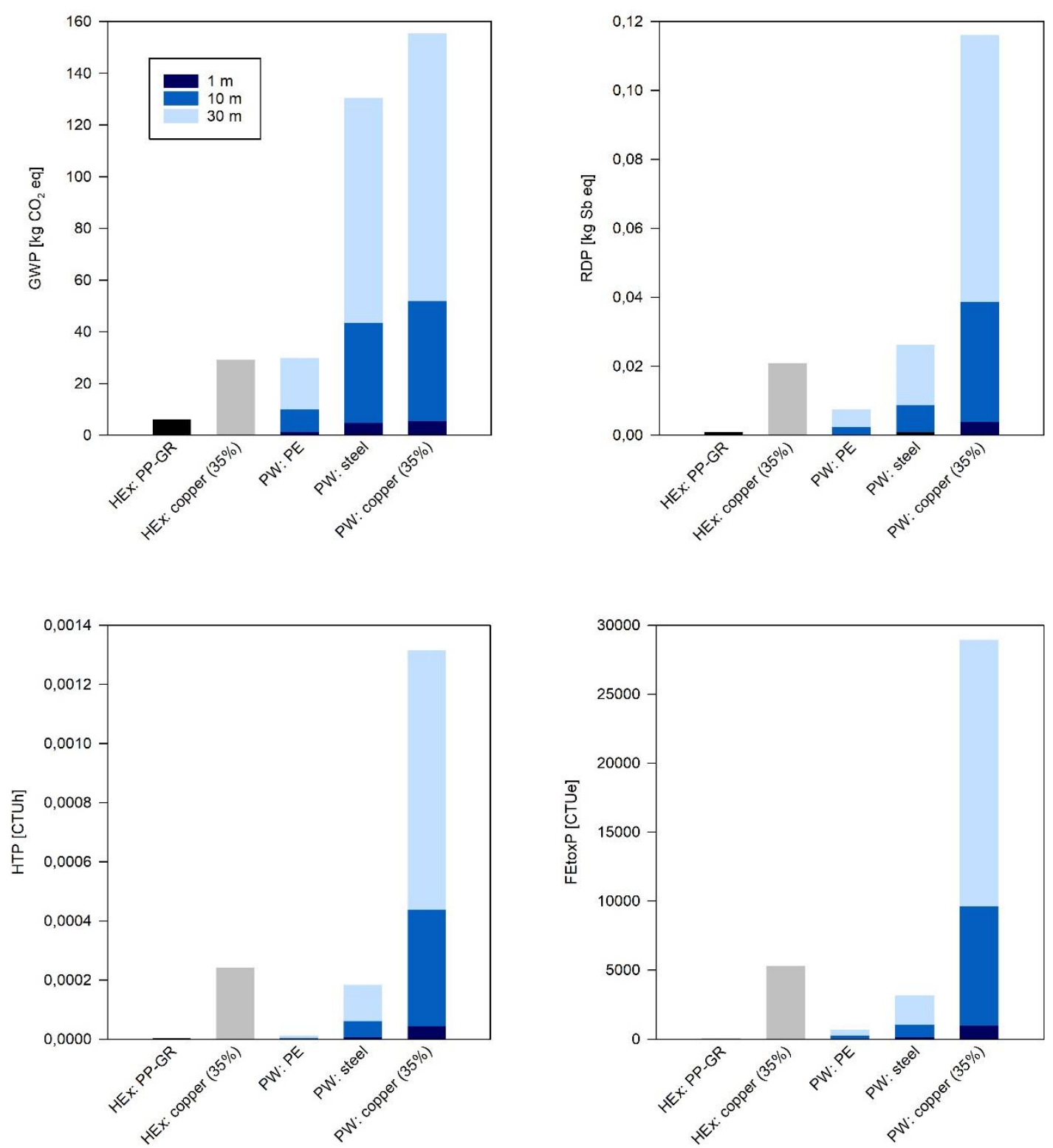

Figure 4: Comparison of LCA results for the heat exchanger and pipework for (clockwise from top left): global

411 warming potential (GWP), resource depletion potential (RDP), freshwater ecotoxicity potential (FEtoxP) and
412 human toxicity potential (HTP). Left two bars: complete life cycle of a heat exchanger system without pipework.

413 Right three bars: life cycle of pipework from polyethylene (PE), steel and copper (35\% recycled content).

\section{$414 \quad 3.2$ Environmental savings through heat recovery}

\section{$415 \quad 3.2 .1 \quad$ Environmental savings in the case study}

416 In the Penrhyn Castle case study, all environmental burdens from the heat recovery system 417 (scenario 2) will be paid back within 10 years when electricity, geo or solar thermal energy or 418 the energy mix for water heating is replaced (Table 3). If the recovered heat replaces natural 419 gas, the impacts of HTP, FEP, FEtoxP and RDP from production, installation and EoL of the 420 heat exchanger and pipework will not be fully paid back in the conservative 10-year lifetime considered in this study. The low FEToxP and RDP of wood heating also prevent payback in the FEtoxP and RDP categories through heat recovery if wood is used for water heating. For GWP, relatively short payback times of under 1.6 years compared with all energy alternatives can be achieved. The payback time for GWP compared to natural gas, the most common 
425 water heating source, is only 0.12 years. This is shorter than the $0.55-1.33$ year GWP payback 426 previously calculated for shower heat recovery (Ip et al., 2018). It underpins the suitability of 427 kitchens for drain water heat recovery due to typically higher wastewater flow-rates than in 428 showers.

429 As the burdens of the PP-GR heat recovery system are substantially lower, they are paid back 430 during shorter periods of operation, within 2 years for all impact categories (Table 3 ).

431 Table 3: Environmental payback times in years for the heat recovery system of the Penrhyn Castle case study. 432 Comparison of the copper (35\% recycled content) and the PP-GR systems including $10 \mathrm{~m}$ of pipework with

433 different energy sources for water heating. Bold and italic: Impacts are not paid back within a 10-year lifetime. NG 434 = natural gas. Mix: Current UK Energy mix for heating water in the service sector (BEIS, 2018). GWP: Global

435 Warming Potential; HTP: Human Toxicity Potential; POFP: Photochemical Ozone Formation Potential; AP:

436 Acidification Potential; FEP: Freshwater Eutrophication Potential; FEToxP: Freshwater Ecotoxicity Potential;

437 RDP: Mineral, fossil \& renewable Resource Depletion Potential. Energy sources as in Table 2.

\begin{tabular}{ccccccc}
\hline Impact category & NG & Electricity & Wood & Geo & Solar & Mix \\
\hline Copper (35\%) & \multicolumn{7}{c}{ [years] } & & & \\
\hline GWP & 0.12 & 0.06 & 0.29 & 0.23 & 1.58 & 0.11 \\
HTP & $\mathbf{1 8 . 8 7}$ & 1.22 & 2.13 & 3.76 & 3.20 & 5.04 \\
POFP & 0.72 & 0.13 & 0.27 & 0.61 & 2.05 & 0.40 \\
AP & 1.82 & 0.16 & 1.19 & 0.60 & 1.90 & 0.68 \\
FEP & $\mathbf{1 2 . 2 0}$ & 0.59 & 8.79 & 1.10 & 3.31 & 3.19 \\
FEtoxP & $\mathbf{1 4 . 1 6}$ & 0.52 & $\mathbf{1 1 . 7 8}$ & 1.72 & 3.51 & 3.02 \\
RDP & $\mathbf{1 4 . 3 2}$ & 2.94 & $\mathbf{3 3 . 4 9}$ & 8.41 & 3.63 & 9.23 \\
\hline PP-GR + PE & & & & [years] & & \\
\hline GWP & 0.02 & 0.01 & 0.05 & 0.04 & 0.27 & 0.02 \\
HTP & 0.16 & 0.01 & 0.02 & 0.03 & 0.03 & 0.04 \\
POFP & 0.08 & 0.01 & 0.03 & 0.07 & 0.23 & 0.04 \\
AP & 0.10 & 0.01 & 0.07 & 0.03 & 0.11 & 0.04 \\
FEP & 0.19 & 0.01 & 0.13 & 0.02 & 0.05 & 0.05 \\
FEtoxP & 0.25 & 0.01 & 0.21 & 0.03 & 0.06 & 0.05 \\
RDP & 0.73 & 0.15 & 1.71 & 0.43 & 0.19 & 0.47 \\
\hline
\end{tabular}




\subsubsection{Environmental savings in UK commercial food outlets}

Two different flow-rates, representing the bottom and top end of the flow-rate spectrum in typical UK food outlets, are taken to show a worst- and best-case scenario for environmental impacts from heat recovery. The best case refers to kitchens with the highest water flow-rate typically found in UK food outlets (12,500 L/day), highest heat recovery potential and therefore the lowest impacts per kWh ("H recov. Low"). The opposite applies to the worst-case scenario with a flow-rate of $360 \mathrm{~L} /$ day ("H recov. High"). The environmental burdens for the heat recovery system are based on scenario 4 (Table 1), including one heat exchanger for the lowflow option and four heat exchangers in parallel for the high-flow option.
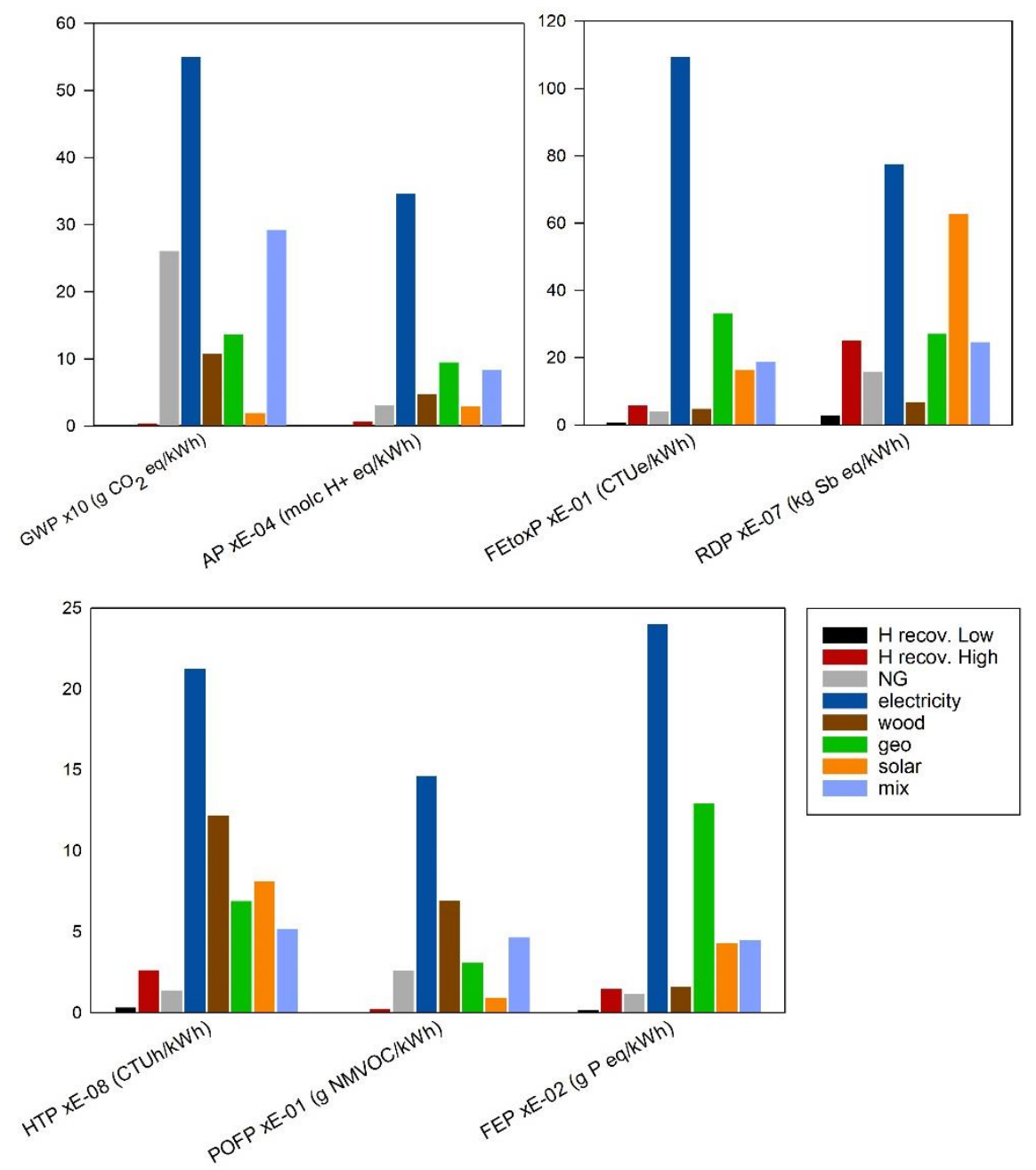

Figure 5: Environmental impacts per kWh for water heating. Comparison of heat recovery from drain water with other renewable and non-renewable heat sources, including the current UK energy mix for water heating ("mix"). Burdens of the heat recovery system as in scenario 4 with two different water flow-rates found in UK commercial food outlets. H recov. Low: low impact case due to higher flow-rate of 12,500 L/day. H recov. High: high impact case due to lower flowrate of 360 L/day. NG: natural gas, electricity: UK grid mix, wood: wood biomass combustion, geo: geothermal, solar: solar thermal. GWP: Global Warming Potential; HTP: Human Toxicity Potential; POFP: Photochemical Ozone Formation Potential; AP: Acidification Potential; FEP: Freshwater Eutrophication Potential; FEToxP: Freshwater Ecotoxicity Potential; RDP: Mineral, fossil \& renewable Resource Depletion Potential.

457 Figure 5 displays the environmental impacts for providing $1 \mathrm{kWh}$ for water heating through heat recovery versus other energy sources. Considering global warming, heating water through the use of recovered heat exhibits the lowest emissions with about 0.4 to $4 \mathrm{~g} \mathrm{CO}_{2}$ equivalent/kWh for the low and high impact scenario, respectively. This compares to 
emissions of 20 to $550 \mathrm{~g} \mathrm{CO}_{2}$ equivalent/kWh for solar thermal and electric water heating i.e. even when currently available heat recovery technology replaces renewable energy sources, GWP can be reduced. Also for ozone formation and acidification, heat recovery at both flow-rates leads to impact savings compared to all other heat sources. In the other categories, environmental sustainability of heat recovery depends on the flow-rate or the heating source replaced. For HTP and FEP, natural gas water heating can have lower environmental impacts compared to heat recovery at low flow-rates. Here, emission savings through heat recovery are only achieved from a flow-rate of about $750 \mathrm{~L} /$ day onwards (HTP) and $555 \mathrm{~L} /$ day (FEP) (values not shown in graph). Similarly, FEtox and RDP can be reduced through heat recovery at higher flow-rates only, when replacing natural gas or wood biomass. With these results a recommendation for drain water heat recovery can be given from a daily flow-rate of $750 \mathrm{~L}$ when natural gas is replaced, the most common source for water heating in the UK.

474 Figure 6 shows the environmental savings that can be achieved during 10 years of heat recovery depending on the flow-rate and replacing the water heating energy mix. Values are shown as normalised scores. The net environmental savings increase with water consumption, although the number of heat exchangers and with them the environmental footprint of the installations augments, too. Apart from RDP, environmental payback is reached within 10 years for all impact categories starting from the lowest average daily water consumption considered (360 L/day) (Spriet and McNabola, 2019a). For RDP, environmental payback within 10 years is only achieved at water consumption rates above approximately $555 \mathrm{~L} /$ day or $300 \mathrm{~m}^{3} /$ year. The greatest normalised savings are achieved in HTP and FEtoxP, followed by GWP, AP, RDP, POFP and FEP in descending order.
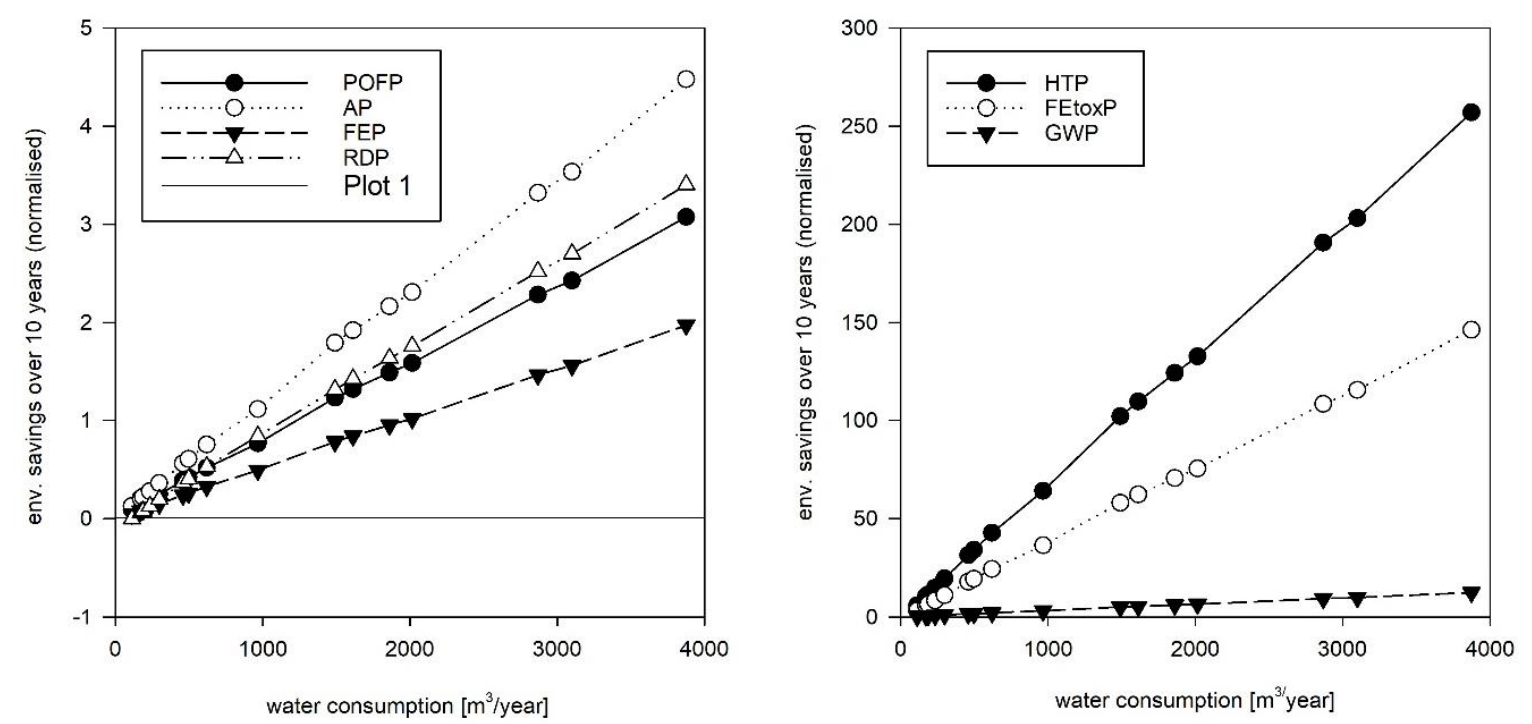

Figure 6: Normalised net environmental savings (positive values) through heat recovery from a commercial kitchen after 10 years depending on the yearly water consumption. GWP: Global Warming Potential; HTP: Human Toxicity Potential; POFP: Photochemical Ozone Formation Potential; AP: Acidification Potential; FEP: Freshwater Eutrophication Potential; FEToxP: Freshwater Ecotoxicity Potential; RDP: Mineral, fossil \& renewable Resource Depletion Potential.

490 Extrapolation of the savings using average daily water consumption rates for the circa 258,000 food outlets in the UK (Backman, 2018; Bromley-Challenor et al., 2013; Spriet and McNabola, 2019a) gives the potential annual environmental savings for the UK (Table 4). Annual GHG emission mitigation of $490 \mathrm{Gg}$ (kilo-tonnes) $\mathrm{CO}_{2}$ equivalent could be avoided if heat from 
wastewater was recovered across all UK commercial food outlets. These environmental savings equate to $30 \%$ of thermal energy needed for water heating in the hospitality and food service sector, based on the share of hot water consumed in the Penrhyn Castle restaurant case study.

The results show that even with the currently available copper heat exchanger and especially at high water consumption rates, there is strong evidence for environmental savings. It can therefore be recommended as a viable measure to de-carbonise water heating in commercial kitchens.

Table 4: Yearly net environmental savings potential for the UK through heat recovery from wastewater in all commercial food outlets. eq = equivalent

\begin{tabular}{lccccccc}
\hline Impact category & GWP & HTP & POFP & AP & FEP & FEtoxP & RDP \\
\hline Unit & {$[\mathrm{kt} \mathrm{CO} 2$ eq] } & {$[\mathrm{CTUh}]$} & {$[\mathrm{t} \mathrm{NMVOC} \mathrm{eq]}$} & $\begin{array}{c}{[1000 \mathrm{molc} \mathrm{H}+} \\
\text { eq] }\end{array}$ & {$[\mathrm{t} \mathrm{P} \mathrm{eq]}$} & {$\left[10^{\wedge} 6 \mathrm{CTUe}\right]$} & {$[\mathrm{kg} \mathrm{Sb}$ eq] } \\
\hline All outlets & 490 & 78 & 772 & 1390 & 70 & 2979 & 3370 \\
\hline
\end{tabular}

Although an economic evaluation of the heat recovery system is out of scope of this study, it is worth mentioning that heat recovery is not only beneficial from an environmental point of view, but also pays back financially from water consumption rates of $960 \mathrm{~L} /$ day (Spriet and

508 McNabola, 2019a).

510

511

512

A study by McNabola and Shields (2013) estimated the heat recovery potential from shower drain water in Ireland to be 808 GWh per year, averaging $577 \mathrm{kWh}$ per year for a 3-person household. Taking into account the population of the UK of $66 \mathrm{M}$ (ONS, 2019) and the UK domestic energy mix for water heating (BEIS, 2018), this would translate to yearly savings of $13 \mathrm{TWh}$ or $3600 \mathrm{Gg} \mathrm{CO}_{2}$ equivalent. Based on the heat recovery system evaluated in this study, the aforementioned annual heat recovery at a household scale would not be financially viable, nor environmentally responsible from a resource depletion perspective.

\section{$517 \quad$ 3.3.1 Expected changes with a changing energy mix}

With a change in the future energy mix towards more renewable sources, the benefit of saving energy through heat recovery is likely to shift from avoiding GHG emissions, to avoiding the depletion of metal and mineral resources. GHG emission savings through heat recovery will be lower as water heating from renewable energy sources emits less GHGs, for both direct electric water heating and thermal water heating with solar collectors or air and ground-source heat pumps (Clarke et al., 2008). Although of course, the GHG emissions of producing the heat recovery system and pipework are also expected to decrease owing to decarbonisation of energy supplies.

Resource depletion burdens are higher for renewable electricity generation (namely wind, solar and hydro power) compared to energy supply from fossil resources owing to large quantities of abiotic resources, especially metals (e.g. manganese, copper, iron, nickel, chrome) required in renewable energy infrastructure (Berrill et al., 2016; Gallagher et al., 2019). The trade-offs between resource depletion and GHG emission savings which currently exist for heat recovery at low flow-rates are therefore likely to disappear.

532 Another important indirect and long-term benefit of heat recovery lies in increasing the efficiency in which energy is used and thus supporting a transformation to a sustainable energy economy through reducing energy demand - a strategy that has been adopted as part 
535 of European and UK policies for future low-carbon energy supply (Clarke et al., 2008; da Graça

536 Carvalho, 2012; Ekins and Lees, 2008; Rosenow, 2012).

\section{$537 \quad 3.3 .2$ Recommendation for further research}

538 As neither the copper nor the PP-GR heat exchanger have been in use with kitchen drain 539 water for significant periods of time, there is room for further research and need for empirical 540 data on real performance. In addition to environmental savings during manufacture, PP-GR and similar composites can offer other potential advantages such as the reduction of scaling in the pipe and thus reduced build-up of an insulating layer inhibiting heat transfer. The behaviour of new materials for this application, but also the behaviour of the conventional copper heat exchanger when used with heavily polluted wastewater such as that from kitchens, requires long-term experimental studies. This will provide more reliable data on heat transfer performance and on required maintenance interventions such as cleaning to remove scaling or fouling. It will also allow more accurate determination of the useful lifetime of the heat exchangers, which will be important for both economic and environmental performance. The lack of accurate data sets and reliance on manufacturer data for modelling the PP-GR material are aspects which should improve with increasing use of such materials.

\section{Conclusions}

552

553

554

555

556

The presented LCA study is the first to evaluate the environmental sustainability of a heat recovery system for harvesting the heat of commercial kitchens' drain water, based on case study data. Different sets of materials are studied for the system, comparing components from conventional copper with alternatives from polypropylene and graphite, as well as polyethylene. The results support the following conclusions:

- The environmental impacts from the copper system, predominantly arising from the production of primary copper, can be reduced substantially through increasing the share of recycled copper as input material.

- A critical factor influencing the material requirement and environmental footprint of any retrofitted (or new) heat recovery system is the length of pipework necessary for connecting the heat exchanger with boiler and cold water supply. We therefore recommend to design the system as compact as possible.

- It is strongly encouraged to consider material choice during the design phase of such installations, including the use of recycled material or new functional materials, such as the polypropylene-graphite composite.

- Heat recovery shows environmental trade-offs with other water heating sources only for flowrates at the lower end of the spectrum of typical water consumption rates in UK food outlets, mainly for resource depletion.

- The amount of recovered heat and with it the environmental savings increase with the water consumption rate, even when environmental capital costs are increased through the installation of several heat exchangers in parallel. Environmental savings across all seven impact categories analysed is achieved for water consumption above $555 \mathrm{~L} /$ day when replacing the heating energy mix.

- Heat recovery from wastewater from food outlets offer a potential solution for saving energy and emissions across the food service sector. When applied across all UK food outlets, GHG emission savings can amount $490 \mathrm{Gg} \mathrm{CO}_{2}$ equivalent per year. 
600

601

602

603

604

605

606

607

608

609

610

611

612

613

614

615

616

617

618

619

620

621

622

Acknowledgement: This research is part of the Dŵr Uisce project, which aims at improving the long-term sustainability of water supply, treatment and end-use in Ireland and Wales. The project has been supported by the European Regional Development Fund (ERDF) Interreg Ireland-Wales Programme 2014-2020.

\section{References}

Althaus, H.J., Classen, M., 2005. Life cycle inventories of metals and methodological aspects of inventorying material resources in ecoinvent. Int. J. Life Cycle Assess. 10, 43-49. https://doi.org/10.1065/lca2004.11.181.5

Arpke, A., Hutzler, N., 2008. Domestic Water Use in the United States: A Life-Cycle Approach. J. Ind. Ecol. 10, 169-184. https://doi.org/10.1162/108819806775545312

Asadi, S., Babaizadeh, H., Foster, N., Broun, R., 2016. Environmental and economic life cycle assessment of PEX and copper plumbing systems: A case study. J. Clean. Prod. 137, 1228-1236. https://doi.org/10.1016/j.jclepro.2016.08.006

Backman, P., 2018. The Foodservice Market. London.

BEIS, 2018. Energy consumption in the UK (ECUK) Table 1.04 [WWW Document]. URL https://www.gov.uk/government/statistics/energy-consumption-in-the-uk (accessed 4.1.19).

Benini, L., Mancini, L., Sala, S., Schau, E., Manfredi, S., Pant, R., 2014. Normalisation method and data for Environmental Footprints, JRC Technical Reports. European Commission, Joint Research Center, Institute for Environment and Sustainability, Publications Office of the European Union, Luxemburg. https://doi.org/10.2788/16415

Berrill, P., Arvesen, A., Scholz, Y., Gils, H.C., Hertwich, E.G., 2016. Environmental impacts of high penetration renewable energy scenarios for Europe. Environ. Res. Lett. 11. https://doi.org/10.1088/1748-9326/11/1/014012

BIF REP, 2013. Building Insulation Foam Resource efficiencty action plan. [WWW Document]. URL www.wrap.org.uk/sites/files/wrap/BIF REAP v2.pdf

BPD Itd., 2019a. Showersave QB1-21 Specification [WWW Document]. URL http://showersave.com/downloads/

BPD Itd., 2019b. Downloads - Showersave [WWW Document]. URL http://www.showersave.com/downloads/ (accessed 2.17.19).

Bromley-Challenor, K., Kowalski, M., Barnard, R., Lynn, S., 2013. Water use in the UK food and drink industry. Technical report. Waste \& Resources Action Programme (WRAP), Banbury, Oxon.

Castro Molinare, J., 2014. Sustainability analysis of copper extraction and processing using LCA methods. Imperial College London.

CDA Inc., 2019. Melt Copper: Furnace types [WWW Document]. Copp. Dev. Assoc. Inc. Copp. Alliance. URL https://www.copper.org/environment/sustainable-energy/electricmotors/education/motor-rotor/production/proc09/process_09_94.html (accessed 2.18.19).

Chen, X., Su, Y., Reay, D., Riffat, S., 2016. Recent research developments in polymer heat exchangers - A review. Renew. Sustain. Energy Rev. 60, 1367-1386. https://doi.org/10.1016/J.RSER.2016.03.024 
Ciacci, L., Vassura, I., Passarini, F., 2017. Urban Mines of Copper: Size and Potential for Recycling in the EU. Resources 6, 6. https://doi.org/10.3390/resources6010006

625

626

627

628

629

630

631

632

633

634

635

636

637

638

639

640

641

642

643

644

645

646

647

648

649

650

651

652

653

654

655

656

657

658

659

660

661

662

663

664

665

666

Clarke, J.A., Johnstone, C.M., Kelly, N.J., Strachan, P.A., Tuohy, P., 2008. The role of built environment energy efficiency in a sustainable UK energy economy. Energy Policy. https://doi.org/10.1016/j.enpol.2008.09.004

da Graça Carvalho, M., 2012. EU energy and climate change strategy. Energy 40, 19-22. https://doi.org/10.1016/j.energy.2012.01.012

Davis, J., He, J., Geyer, R., Sansom, M., Ley, J., Clift, R., Kwan, A., Jackson, T., 2006. Time-dependent material flow analysis of iron and steel in the UK. Resour. Conserv. Recycl. 51, 118-140. https://doi.org/10.1016/j.resconrec.2006.08.007

DEFRA, 2008. Future Water: The Government's water strategy for England. Norwich, UK.

Dötsch, E., 2017. Use of thermochemical data in inductive melting. Dortmund, Germany.

Ecoinvent, 2018. Ecoinvent V3.5 Database. Zurich, Switzerland.

Ekins, P., Lees, E., 2008. The impact of EU policies on energy use in and the evolution of the UK built environment. Energy Policy. https://doi.org/10.1016/j.enpol.2008.09.006

Ekvall, T., Tillman, A.M., 1997. Open-loop recycling: Criteria for allocation procedures. Int. J. Life Cycle Assess. 2, 155-162. https://doi.org/10.1007/BF02978810

EST, 2013. At Home with Water. London.

Fagan, J.E., Reuter, M.A., Langford, K.J., 2010. Dynamic performance metrics to assess sustainability and cost effectiveness of integrated urban water systems. Resour. Conserv. Recycl. 54, 719-736. https://doi.org/10.1016/J.RESCONREC.2009.12.002

Franklin Associates, 2011. LIFE CYCLE INVENTORY FOR THE PRODUCTION AND USE OF INSTALLED RESIDENTIAL PIPING SYSTEMS FOR THREE HOUSE LAYOUTS. Plastic Piping Education Foundation.

Gallagher, J., Basu, B., Browne, M., Kenna, A., McCormack, S., Pilla, F., Styles, D., 2019. Adapting Stand-Alone Renewable Energy Technologies for the Circular Economy through Eco-Design and Recycling. J. Ind. Ecol. 23, 133-140. https://doi.org/10.1111/jiec.12703

Geberit Sales Ltd, 2019. Geberit Mapress Stainless Steel system pipe: Product Data Sheet [WWW Document]. URL https://catalog.geberit.co.uk/en-GB/Geberit-MapressStainless-Steel-system-pipe,-CrNiMo,-small-bundle/OVE_502637-39202.html (accessed 4.9.19).

Gerbens-Leenes, P.W., 2016. Energy for freshwater supply, use and disposal in the Netherlands: a case study of Dutch households. Int. J. Water Resour. Dev. 32, 398411. https://doi.org/10.1080/07900627.2015.1127216

German Pipe, 2019. German Pipes - copper pipes [WWW Document]. URL https://www.germanpipe.de/domains/germanpipe_de/data/free_docs/gp_system_ekomponenten_kupfer_edelstahl_en.pdf

Giurco, D., Petrie, J.G., 2007. Strategies for reducing the carbon footprint of copper: New technologies, more recycling or demand management? Miner. Eng. 20, 842-853. https://doi.org/10.1016/j.mineng.2007.04.014

Glade, H., Moses, D., Orth, T., 2018. Polymer Composite Heat Exchangers, in: Bart, H.-J., Scholl, S. (Eds.), Innovative Heat Exchangers. Springer International Publishing AG, pp. 53-116. 
Glöser, S., Soulier, M., Tercero Espinoza, L.A., 2013. Dynamic analysis of global copper flows. Global stocks, postconsumer material flows, recycling indicators, and uncertainty evaluation. Environ. Sci. Technol. 47, 6564-6572. https://doi.org/10.1021/es400069b

Hussain, A.R.J., Alahyari, A.A., Eastman, S.A., Thibaud-Erkey, C., Johnston, S., Sobkowicz, M.J., 2017. Review of polymers for heat exchanger applications: Factors concerning thermal conductivity. Appl. Therm. Eng. 113, 1118-1127. https://doi.org/10.1016/J.APPLTHERMALENG.2016.11.041

Ip, K., She, K., Adeyeye, K., 2018. Life-cycle impacts of shower water waste heat recovery: case study of an installation at a university sport facility in the UK. Environ. Sci. Pollut. Res. 25, 19247-19258. https://doi.org/10.1007/s11356-017-0409-0

ISO, 2006. ISO 14040:2006 - Environmental management -- Life cycle assessment -Principles and framework [WWW Document]. Int. Organ. Stand. URL https://www.iso.org/standard/37456.html (accessed 2.14.19).

Johnson, J.X., McMillan, C., Keoleian, G.A., 2013. Evaluation of Life Cycle Assessment Recycling Allocation Methods. J. Ind. Ecol. 17. https://doi.org/10.1111/jiec.12050

JRC-IES, E., 2011. ILCD handbook. Recommendations for Life Cycle Impact Assessment in the European context, International Reference Life Cycle Data System (ILCD) Handbook, Recommendations for life cycle impact assessment in the European context. European Commission - Joint Research Centre - Institute for Environment and Sustainability (EC JRC-IES) Publication Office of the European Union, Luxemburg. https://doi.org/10.2788/33030

Livingston, T., 2018. Personal communication, Tony Livingston, 30th July 2018.

Manouchehri, R., Banister, C.J., Collins, M.R., 2015. Impact of small tilt angles on the performance of falling film drain water heat recovery systems. Energy Build. 102, 181186. https://doi.org/10.1016/J.ENBUILD.2015.05.024

McNabola, A., Shields, K., 2013. Efficient drain water heat recovery in horizontal domestic shower drains. Energy Build. 59, 44-49. https://doi.org/10.1016/j.enbuild.2012.12.026

Mudgal, S., Lyons, L., Bain, J., Dias, D., Faninger, T., Johansson, L., Dolley, P., Shields, L., Bowyer, C., 2011. Plastic waste in the environment - Final Report. European Commission (DG Environment).

Nair, S., George, B., Malano, H.M., Arora, M., Nawarathna, B., 2014. Water-energygreenhouse gas nexus of urban water systems: Review of concepts, state-of-art and methods. Resour. Conserv. Recycl. 89, 1-10. https://doi.org/10.1016/J.RESCONREC.2014.05.007

Olson, D.W., Virta, R.L., Mahdavi, M., Sangine, E.S., Fortier, S.M., 2016. Natural graphite demand and supply - Implications for electric vehicle battery requirements, in: Wessel, G.R., Greenberg, J.K. (Eds.), Geoscience for the Public Good and Global Development : Toward a Sustainable Future. Geological Society of America, pp. 67-77.

ONS, 2019. Population estimates for the UK, England and Wales, Scotland and Northern Ireland: mid-2018 [WWW Document]. Stat. Bull. Off. Natl. Stat. URL https://www.ons.gov.uk/peoplepopulationandcommunity/populationandmigration/popula tionestimates/bulletins/annualmidyearpopulationestimates/mid2018 (accessed 4.23.20).

Pipelife UK, 2019. Qual-Pex Barrier Pipe Specification [WWW Document]. URL https://www.pipelife.co.uk/uk/product_overview/Qual-Pex_Barrier_Pipe.php (accessed 4.9.19).

PRé Sustainability, 2018. SimaPro 9.0. 3818 LE Amersfoort, The Netherlands. 
Prek, M., 2004. Environmental impact and life cycle assessment of heating and air conditioning systems, a simplified case study. Energy Build. 36, 1021-1027. https://doi.org/10.1016/J.ENBUILD.2004.06.008

Q-Blue b.v., 2019. Q-Blue Showersave [WWW Document]. URL https://www.qblue.nl/en/products/q-blue-showersave-en (accessed 2.13.19).

Q-Blue b.v., 2018. Installation Manual Showersave QB1-12-16-21 [WWW Document]. https://doi.org/http://dx.doi.org/10.1016/j.metabol.2013.01.021

RenewABILITY Energy Inc., 2019. RenewABILITY Energy Inc. - Home of the Power-Pipe Drain Water Heat Recovery System [WWW Document]. URL http://renewability.com/ (accessed 2.13.19).

Rosenow, J., 2012. Energy savings obligations in the UK-A history of change. Energy Policy. https://doi.org/10.1016/j.enpol.2012.06.052

Ruhrberg, M., 2006. Assessing the recycling efficiency of copper from end-of-life products in Western Europe. Resour. Conserv. Recycl. 48, 141-165. https://doi.org/10.1016/j.resconrec.2006.01.003

Sanders, K.T., Webber, M.E., 2012. Evaluating the energy consumed for water use in the United States. Environ. Res. Lett. 7, 034034. https://doi.org/10.1088/17489326/7/3/034034

Schuitema, R., Sijpheer, N.C., Bakker, E.J., 2005. Energy performance of a drainwater heat recovery system. Experimental results of drainwater heat recovery in ECN research dwellings, in: CISBAT Conference. Lausanne, Switzerland, p. 7.

Siddiqi, A., Fletcher, S., 2015. Energy Intensity of Water End-Uses. Curr. Sustain. Energy Reports 2, 25-31. https://doi.org/10.1007/s40518-014-0024-3

Słyś, D., Kordana, S., 2014. Financial analysis of the implementation of a Drain Water Heat Recovery unit in residential housing. Energy Build. 71, 1-11. https://doi.org/10.1016/J.ENBUILD.2013.11.088

Spriet, J., McNabola, A., 2019a. Decentralized drain water heat recovery from commercial kitchens in the hospitality sector. Energy Build. 194, 247-259.

Spriet, J., McNabola, A., 2019b. Drain Water Heat Recovery in Commercial Kitchens: Case of Tourist Attraction, 14th Conference on Sustainable Development of Energy, Water and Environment Systems (SDEWES). https://www.dwr-uisce.eu/conferenceproceedings-and-posters, Dubrovnik.

Technoform, 2014. FULL POLYMER HEAT-EXCHANGER TUBES. Technoform Kunststoffprofile GmbH, Otto-Hahn-Str 34, 34253 Lohfelden, Germany.

Tikana, L., Sievers, H., Klassert, A., 2005. Life Cycle Assessment of Copper Products. Düsseldorf, Germany. https://doi.org/10.1007/BF02979447

van der Hoek, J., 2011. Energy from the water cycle: a promising combination to operate climate neutral. Water Pract. Technol. 6.

Wong, L.T., Mui, K.W., Guan, Y., 2010. Shower water heat recovery in high-rise residential buildings of Hong Kong. Appl. Energy 87, 703-709. https://doi.org/10.1016/J.APENERGY.2009.08.008 
755 Figure and Table Captions:

Figure 1: System boundaries of the LCAs on the heat recovery system (left, shown for the copper system) and extended boundaries for evaluating the savings potential through the replacement of heat energy sources.

Figure 2: Environmental burdens arising from the life cycle of drain water heat recovery systems consisting of inline heat exchanger, $10 \mathrm{~m}$ pipework, fittings and insulations. Percentage in brackets stands for the share of recycled copper. PE: polyethylene, PP-GR: Polypropylene-Graphite. GWP: Global Warming Potential; HTP: Human Toxicity Potential; POFP: Photochemical Ozone Formation Potential; AP: Acidification Potential; FEP: Freshwater Eutrophication Potential; FEToxP: Freshwater Ecotoxicity Potential; RDP: Mineral, fossil \& renewable Resource Depletion Potential. All scenarios as described in Table 1.

Figure 3: LCA of heat recovery systems (scenarios 2 and 5): Relative contribution of the life cycle stages to the environmental impacts of the two heat recovery systems including $10 \mathrm{~m}$ pipework. Left: scenario 2: copper system with 35\% recycled copper input. Right: scenario 5: PP-GR composite system with PP-GR heat exchanger and pipework from PE. GWP: Global Warming Potential; HTP: Human Toxicity Potential; POFP: Photochemical Ozone Formation Potential; AP: Acidification Potential; FEP: Freshwater Eutrophication Potential; FEToxP: Freshwater Ecotoxicity Potential; RDP: Mineral, fossil \& renewable Resource Depletion Potential; Hex: Heat exchanger; EoL: End of Life.

Figure 4: Comparison of LCA results for the heat exchanger and pipework for (clockwise from top left): global warming potential (GWP), resource depletion potential (RDP), freshwater ecotoxicity potential (FEtoxP) and human toxicity potential (HTP). Left two bars: complete life cycle of a heat exchanger system without pipework. Right three bars: life cycle of pipework from polyethylene (PE), steel and copper (35\% recycled content).

Figure 5: Environmental impacts per kWh for water heating. Comparison of heat recovery from drain water with other renewable and non-renewable heat sources, including the current UK energy mix for water heating ("mix"). Burdens of the heat recovery system as in scenario 4 with two different water flow-rates found in UK commercial food outlets. H recov. Low: low impact case due to higher flow-rate of 12,500 L/day. H recov. High: high impact case due to lower flowrate of 360 L/day. NG: natural gas, electricity: UK grid mix, wood: wood biomass combustion, geo: geothermal, solar: solar thermal. GWP: Global Warming Potential; HTP: Human Toxicity Potential; POFP: Photochemical Ozone Formation Potential; AP: Acidification Potential; FEP: Freshwater Eutrophication Potential; FEToxP: Freshwater Ecotoxicity Potential; RDP: Mineral, fossil \& renewable Resource Depletion Potential

Figure 6: Normalised net environmental savings (positive values) through heat recovery from a commercial kitchen after 10 years depending on the yearly water consumption. GWP: Global Warming Potential; HTP: Human Toxicity Potential; POFP: Photochemical Ozone Formation Potential; AP: Acidification Potential; FEP: Freshwater Eutrophication Potential; FEToxP: Freshwater Ecotoxicity Potential; RDP: Mineral, fossil \& renewable Resource Depletion Potential.

789 Table 1: Overview of assumptions for scenarios of the LCAs.

Table 2: Types of energy and respective database modules used for determination of environmental savings 791 through heat recovery

Table 3: Environmental payback times in years for the heat recovery system of the Penrhyn Castle case study. Comparison of the copper (35\% recycled content) and the PP-GR systems including $10 \mathrm{~m}$ of pipework with different energy sources for water heating. Bold and italic: Impacts are not paid back within a 10-year lifetime. NG = natural gas. Mix: Current UK Energy mix for heating water in the service sector (BEIS, 2018). GWP: Global Warming Potential; HTP: Human Toxicity Potential; POFP: Photochemical Ozone Formation Potential; AP: Acidification Potential; FEP: Freshwater Eutrophication Potential; FEToxP: Freshwater Ecotoxicity Potential; RDP: Mineral, fossil \& renewable Resource Depletion Potential. Energy sources as in Table 2. 